\title{
HUBUNGAN KARAKTERISTIK IBU (USIA, PARITAS, PENDIDIKAN) DAN DUKUNGAN SOSIAL SUAMI DENGAN KEIKUTSERTAAN SENAM HAMIL DI DESA PANDANMULYO
}

\author{
Era Nurisa Windari, SST, M.Kes ${ }^{1 *}$, Rismaina Putri, SST, M.Keb ${ }^{2}$, Siti Nur Astriani ${ }^{3}$ \\ "S1 Kebidanan Fakultas Kedokteran Universitas Brawijaya \\ Email* : ersawibowo@gmail.com \\ HP : +6282141687999
}

\begin{abstract}
Pregnancy is process started from conception till the the fetus birth. Duringpregnant women, their experience will be changes in both oftheir physiological and psychological. The Indonesia health government give some solutions for their worriedone of the programs that will resolve of the problems that is expected to overcome the problem is pregnancy physical exercise. Pregnant exercise is a motion physical exercise that is used for a therapeutic preparation in readiness of pregnant women. There are a lot of factors that influence the participation of mothers including the characteristics of the mother. The characteristic which is women intrapersonal factor is the factor of itself which includes such as parity, age and education as well as social support in pregnancy exercise. Social support that leads to appreciate or assistance and also the attentionprovided by others or groups, especially the support of a spouse/husband. This study aims to determine that the relation between the characteristics (parity, age and education) and than social support of their husband's with the participation of exercise in pregnancy atplace area Pandanmulyo Village Tajinan Sub-District Malang Regency 2017. The research design used by researchers is analytic observational where the researcher use 35 respondentsthat's taken using total sampling method with the result of exercise in pregnancy participation as much as $57.1 \%$ or followed by 25 respondents. Data analysis was tested using Chi Square with characteristic result that is age, parity and education with $p$ value $=0.006,0.046,0.018$ and husband's social support show result with the $p$ value $=0.025$. From this results, it can be concluded that there is a significant relation between dependent and independent variable that's characteristics of the mother (parity, age, education) and husband's social support for pregnancy exercise in their participation.
\end{abstract}

Keywords: parity, education, age, social support of husband, exercise in pregnancy

\section{ABSTRAK}


Kehamilan merupakan suatu proses berkesinambungan yang mana dari mulai terjadinya konsepsi hingga lahirnya janin. Pada masa kehamilan, wanita akan mengalami berbagai perubahan baik perubahan psikologis maupun perubahan fisiologis. Salah satu progam yang dicanangkan oleh pemerintah yang mana diharapkan dapat mengatasi masalah tersebut yaitu senam hamil. Senam hamil merupakan latihan gerak sebagai terapi pembekalan dalam kesiapan ibu hamil baik secara fisiologis maupun psikologis.Beberapa faktor yang berpotensi mempengaruhi keikutsertaan ibu dalam senam hamil diantaranya pendidikan, usia, paritas dab dukungan sosial. Dukungan sosial yang diberikan melalui penghargaan, perhatian atau bantuan yang diberikan oleh suatu kelompok atau individu lain, khususnya yaitu dukungan dari pasangan. Penelitian ini bertujuan untuk dapat mengetahui serta mengidentifikasi hubungan antara karakteristik ibu (paritas, usia,pendidikan) dan sosial dukungan suami dengan keikut sertaan senam hamil di Desa Pandanmulyo Wilayah Kerja Puskesmas Tajinan Kabupaten Malang tahun 2017. Observasional analiltik merupakan desain penelitian yang digunakan oleh peneliti yang mana peneliti menggunakan metode pendekatan crosssectional terhadap 35 responden yang diambil menggunakan metode total sampling dengan hasil univariat keikutsertaan senam hamil sebanyak 57,1\%atau sebanyak 25 responden. Analisa data diuji menggunakan ChiSquare dengan hasil karakteristik yaitu meliputi usia, paritas dan pendidikan dengan masing-masing $p$ value $=0,006 ; 0,046 ; 0,018$ dan dukungan sosial suami menunjukan hasil $p$ value $=0,025$. Dari hasil tersebut dapat disimpulkan bahwa terdapat hubungan positif yang signifikan antara karakteristik ibu (usia, paritas dan pendidikan) dan dukungan sosial suami terhadap keikutsertaan senam hamil.

Kata kunci: paritas, usia, pendidikan, dukungan sosial suami, senam hamil

*Korespondensi: Era Nurisa Windari. Surel: ersawibowo@gmail.com 


\section{PENDAHULUAN}

Kehamilan adalah suatu proses berkesinambungan yang dimulai dengan terjadinya ovulasi, jika telah masanyamaka terjadinya pembentukan plasenta sampai tumbuh kembang hasil konsepsi hingga aterm. ${ }^{1}$ Pada masa kehamilan,seorang wanita akan mengalami banyak perubahan yang terjadi. Sebagian dari wanita dapat beradaptasi, namun sebagian lainnya tidak terutama pada perubahan fisik yang dialaminya. Salah satu upaya pemerintah dalam mengatasi permasalahan tersebut yaitu dengan membentuk program pada masa kehamilan yang mana berupa kelas ibu hamil.2

$\mathrm{Di}$ Indonesia masih belum diketahui secara pasti angka dari keikutsertaan wanita hamil yang melakukan kegiatan senam hamil. Namun jika dilihat dari kegiatan kelas ibu hamil dimana didalam program ini senam hamil merupakan salah satu item didalamnya. Senam hamil merupakan latihan gerakan yang dipersiapkan bagi ibu hamil. Senam hamil tidak hanya bermanfaat dalam proses persalinan yang mana melibatkan kekuatan serta dapat mempertahankan kelenturan dari berbagai macam otot baik otot dasar panggul kelak namun juga pada otot-otot dinding perut. Namun dapat juga melatih sikap tubuh ibu untuk dapat menghindari atau meringankan keluhan yang dialami selama masa kehamilan. Banyak faktor yang dapat mempengaruhi keikutsertaan ibu dalam mengikuti senam hamil diantaranya karakteristik yang mana merupakan faktor intrapersonal ibu yaitu faktor dari dirinya sendiri yang meliputi paritas, usia dan pendidikan, status bekerja serta penghasilan. ${ }^{3}$ Adapun faktor dukungan sosial juga dapat mempengaruhi dalam membangun kesadaran maupun motivasi untuk turutserta dalam kegiatan yang berbasis kesehatan. Dukungan sosial ini dapat didapatkan baik dari keluarga, pasangan, maupun tenaga kesehatan, dukungan sosial khususnya dukungan yang diberikan oleh pasangan sangat diharapkan kehadirannya. ${ }^{4,12}$

Berdasarkan studi pendahuluan yang telah dilaksanakan peneliti di Desa Pandanmulyo Kecamatan Tajinan Kabupaten Malang dan di dapatkan hasil bahwa tingkat keikutsertaan senam hamil di fasilitas kesehatan dengan hasil dimana dengan tingkat partisipasi senam hamil pada Puskesmas Tajinan dengan tingkat keikutsertaan senam hamil mengalami penurunan rata-rata $75 \%$ pada tahun 2016 dimana sebelumnya berada pada nilai rata-rata $80 \%$ di tahun 2015. Adapun tingkat keikutsertaan senam hamil terendah terdapat di Desa Pandanmulyo ditahun 2015 rata-rata $75 \%$ sedangkan pada tahun 2016 ratarata $70 \%$ yang merupakan wilayah kerja Puskesmas Tajinan. ${ }^{5}$

Dari fenomena yang telah didapatkan tersebut diatas dan mengingat pentingnya senam hamil maka peneliti untuk mengidentifikasi hubungan karakteristik(paritas, usia, pendidikan) dan sosial dukungan suami terhadap keikutsertaan senam hamil di di desa Pandanmulyo yang merupakan Wilayah Kerja dari Puskesmas Tajinan Kabupaten Malang.

\section{METODE PENELITIAN}

Desain penelitian observasional analitik yang digunakan oleh peneliti yang mana menggunakan metode cross sectiional. Data yang diambil berupa data primer maupun data sekunder. Pengambilan data primer yaitu menggunakan kuesioner serta data sekunder atau data dukung yaitu diambil dari buku Kunjungan Ibu dan Anak (KIA) responden yang dipergunakan untuk melihat usia kehamilan ibu. Penelitian ini telah dilaksanakan pada bulan OktoberDesember 2017 di Desa Pandanmulyo 
Wilayah Kerja Puskesmas Tajinan Kabupaten Malang.

Sampel pada penelitian ini yaitu seluruh dari ibu hamil yang sesuai dengan kriteria yang ditetapkan peneliti dan terpilih untuk dijadikan sampel penelitian yaitu sebanyak 35 responden. Metode teknik sampling pada penelitian ini yaitu menggunakantotal sampling.Kriteria inklusi yaitu:(1) lbu hamil dengan usia kehamilan $>22$ minggu di Desa Pandanmulyo Wilayah Kerja Puskesmas Tajinan Kabupaten Malang bulan September sampai dengan November 2017; (2) Ibu tidak buta huruf; (3) Ibu bersedia mengisi kuisioner / di wawancarai. Untuk kriteria eksklusi yaitu: (1) ibu hamil dengan komplikasi (serviks inkompeten, heart disease, lung disease, pregnancy kebar, history of vaginal bleedingin the second and third trimesters, severe anemia, placental revia, atonia urteri, irregular heart rhythm); (2) suami di luar kota dalam waktu $\geq 1$ bulan; (3) ibu yang mengalami tuna rungu dan tuna wicara; (4) ibu hamil yang tidak memiliki suami (janda).

Analisis data yang dilakukan pada penelitian ini yaitu dengan menggunakan aplikasi SPSS versi 22 yang terdiri dari analisis univariat serta bivariat. Dimanaa analisa bivariate uji chis square yang dipilih yaitu untuk mengettahui hubungan karakteristik responden penelitian (usia, paritas dan pendidiikan) dengan keikutsertaan senam hamil serta dukungan sosial suami dengan keikutsertaan senam hamil dengan derajat kepercayaan sebesar 95\%. Hasil dari penelitian yang telah dilakukan akan dikatakan bermakna dengan tingkat signifikansi $0,005(p=<0,05)$ yang mana dapat diinterpretasikan bahwasannya terdapat hubungan baik variabel independen diengan variabel dependen dengan cara mendeskripsikan masingmasing variable dalam bentuk diagram distribusi, frekuensi dan narasi.
HASIL PENELITIAN

1. Uji Univariat

Tabel 1 Distribusi

FrekuensiKeikutsetaan Senam Hamil

Keikutsertaan Senam Hamil

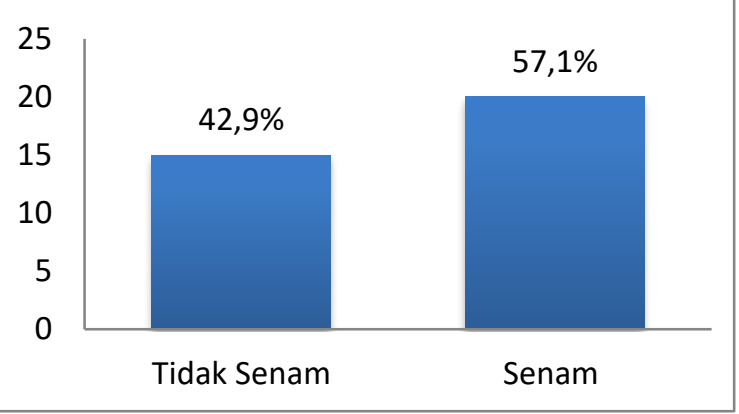

Dari hasil tabel tersebut diatas diketahui bahwa responden penelitian yang mengikuti senam hamil sebanyak 20 responden $(57,1 \%)$, sedangkan responden penelitian yang tidak mengikuti senam hamil sebanyak 15 responden $(42,9 \%)$.

Tabel 2 Distribusi Frekuensi Usia

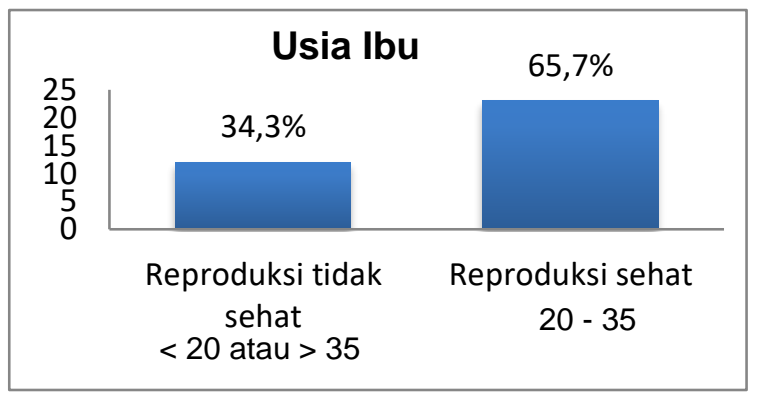

Dari tabel 2 diatas dapat diketahui bahwa usia responden yang menjadi sampel yaitu 12 responden (34,3\%) usia reproduksi ibu tidak sehat, untuk usia reproduksi ibu sehat sebanyak 23 responden $(65,7 \%)$. Dari data tersebut dapat disimpulkan bahwa rata-rata ibu yang menjadi sampel masih berada dalam usia produktif yaitu usia $20-35$ tahun sebanyak 23 responden $(65,7 \%)$ dari total sebanyak 35 responden ibu hamil.

Tabel 3 Distribusi Frekuensi Paritas

\begin{tabular}{c|l|l}
\hline 30 & Paritas Ibu & $68,6 \%$ \\
20 & $31,4 \%$ \\
10 & \\
\hline 0 &
\end{tabular}


Dari tabel 3 diketahui hasil dari data penelitian yang telah dilakukan ditinjau dari segi paritas responden lebih banyak pada kelompok multipara yaitu sebanyak 24 responden $(68,6 \%)$ dan untuk responden pada kelompok primipara sebanyak 11 responden $(31,4 \%)$.

Tabel 4 Distribusi Frekuensi

Pendidikan

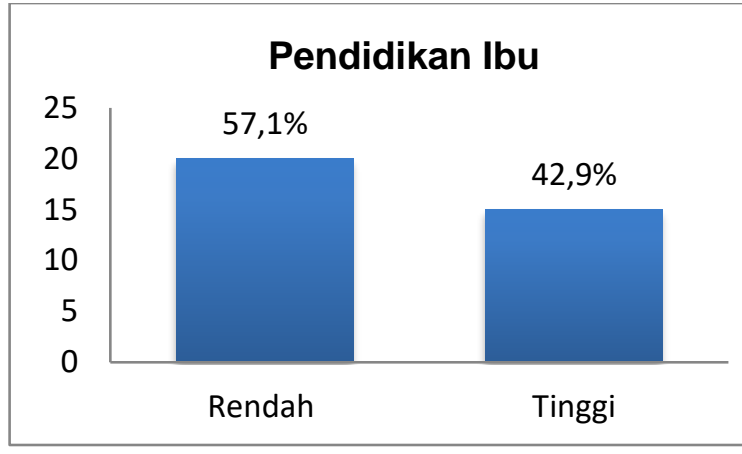

Dari diatas diketahui bahwa pendidikan responden dengan persentase pendidikan ibu hamil yang telah atau sedang menempuh pendidikan dalam kategori pendidikan rendah sebanyak 20 responden ibu hamil $(57,1 \%)$, sedangkan ibu hamil yang termasuk dalam kategori pendidikan tinggi sebanyak 15 responden ibu hamil $(42,9 \%)$.

Tabel 5 Distribusi Frekuensi Dukungan Sosial Suami

Dukungan Sosiial Suami $\quad$ Frequency (f) $\quad$ Precentage (\%)

\section{Dukungan Emosiional}

Rendah

Tinggi

Dukungan Instrumental

Rendah

24

Tiinggi

11

Dukungan Informasional

Rendah

16

Tinggi

19

Dukungan Appraisal

Rendah

Tiinggi
31,4

54,3

28,6

71,4

68,6

45,7

54,3

Dukungan Sosial Suami

Rendah 
Tabel 6 Tabulasi Silang antara Karakteristik Ibu (Usia, Paritas, Pendidikan) dengan Keikutsertaan Senam Hamil

\begin{tabular}{|c|c|c|c|c|c|c|c|}
\hline \multirow{3}{*}{ Karakteristik Ibu } & \multicolumn{4}{|c|}{$\begin{array}{c}\text { Keikutsertaan Senam } \\
\text { Hamil }\end{array}$} & \multicolumn{2}{|c|}{ Total } & \multirow{3}{*}{$\mathrm{p}$ value } \\
\hline & \multicolumn{2}{|c|}{$\begin{array}{c}\text { Tidak } \\
\text { Senam }\end{array}$} & \multicolumn{2}{|c|}{ Senam } & \multirow[t]{2}{*}{$\Sigma$} & \multirow[t]{2}{*}{$\%$} & \\
\hline & $\mathbf{n}$ & $\%$ & $\mathbf{n}$ & $\%$ & & & \\
\hline Usia & & & & & & & \\
\hline Reproduksi tidak sehat & 9 & 25,7 & 3 & 8,6 & 12 & 34,3 & 0,006 \\
\hline Reproduksi sehat & 6 & 17,1 & 17 & 48,6 & 23 & 65,7 & \\
\hline Paritas & & & & & & & \\
\hline Primipara & 2 & 5,7 & 9 & 25,7 & 11 & 31,4 & 0,046 \\
\hline Multipara & 13 & 37.1 & 11 & 31,4 & 24 & 68.6 & \\
\hline Pendidikan & & & & & & & \\
\hline SD-SMP (rendah) & 12 & 34,3 & 8 & 22,9 & 20 & 57,1 & 0,018 \\
\hline SMA-PT (tinggi) & 3 & 8,6 & 12 & 34,3 & 15 & 42,9 & \\
\hline
\end{tabular}

Tabel 7 Tabulasi Silang antara Dukungan Sosial Suami dengan Keikutsertaan Senam Hamil

\begin{tabular}{|c|c|c|c|c|c|c|c|}
\hline \multirow{3}{*}{ Dukungan Sosial Suami } & \multicolumn{4}{|c|}{$\begin{array}{c}\text { Keikutsertaan senam } \\
\text { hamil }\end{array}$} & \multicolumn{2}{|c|}{ Total } & \multirow{3}{*}{$\begin{array}{c}\mathrm{p} \\
\text { value }\end{array}$} \\
\hline & \multicolumn{2}{|c|}{$\begin{array}{c}\text { Tidak } \\
\text { senam }\end{array}$} & \multicolumn{2}{|c|}{ Senam } & \multirow[t]{2}{*}{$\Sigma$} & \multirow[t]{2}{*}{$\%$} & \\
\hline & $\mathbf{n}$ & $\%$ & $\mathbf{n}$ & $\%$ & & & \\
\hline \multicolumn{7}{|l|}{ Dukungan emosi } & \multirow{3}{*}{0,005} \\
\hline Riendah & 8 & $22,9 \%$ & 2 & $5,7 \%$ & 10 & $28,6 \%$ & \\
\hline Tinggi & 7 & $20,0 \%$ & 18 & $51,4 \%$ & 25 & $71,4 \%$ & \\
\hline \multicolumn{7}{|l|}{ Dukungan instrumen } & \multirow{3}{*}{0,006} \\
\hline Rendah & 14 & $40,0 \%$ & 10 & $28,6 \%$ & 24 & $68,6 \%$ & \\
\hline Tinggi & 1 & $2,9 \%$ & 10 & $28,6 \%$ & 11 & $31,4 \%$ & \\
\hline \multicolumn{7}{|l|}{ Dukungan informasi } & \multirow{2}{*}{0,031} \\
\hline Rendah & 10 & $28,6 \%$ & 6 & $17,1 \%$ & 16 & $45,7 \%$ & \\
\hline
\end{tabular}




$\begin{array}{lllllll}\text { Tinggi } & 5 & 14,3 \% & 14 & 40,0 \% & 19 & 54,3 \%\end{array}$

Dukunganpenghargaan

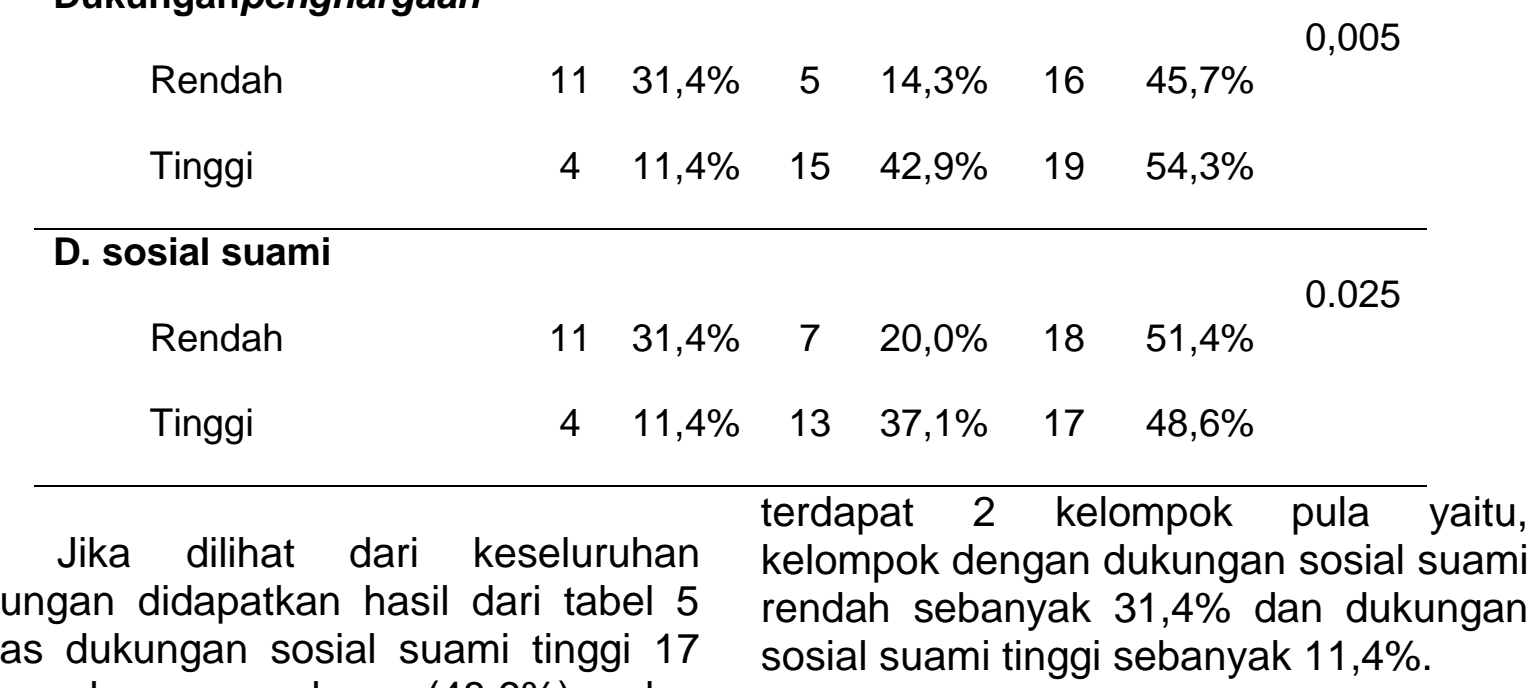

sebanyak responden $(48,6 \%)$ dan dukungan sosial suami rendah 18 sebanyak responden $(51,4 \%)$, hal ini menunjukkan bahwa lebih banyak responden yang mendapatkan dukungan sosial suami rendah.

Berdasarkan tabel 6 diatas bahwa dari 35 responden yang mana ditinjau dari usia responden dibagi menjadi 2 kelompok yaitu usia reproduksi tidak sehat dan usia reproduksi sehat, yang mana pada usia reproduksi tidak sehat tingkat keikutsertaan senam hamil hanya berkisar sebesar $8,6 \%$ atau sebanyak 3 responden sedangkan pada kelompok usia reproduksi sehat tingkat keikutsertaan senam hamil jauh lebih tinggi yaitu sebesar $48,6 \%$ atau sebanyak 17responden. Sedangkan pada responden yang tidak mengikuti senam hamil pada usia reproduksi tidak sehat sebanyak 9 responden (25,7\%) dan responden dengan usia reproduksi sehat sebanyak 6 responden $(17,1 \%)$.

Berdasarkan hasil dari tabel 7 yang tersaji diatas dukungan sosial suami secara keseluruhan dengan keikutsertaan senam hamil terdapat 2 kelompok yaitu, yaitu dukungan sosial suami tinggi sebanyak $37,1 \%$ dan pada kelompok dukungan sosial suami rendah sebanyak 20,0\%, sedangkan berdasarkan dukungan sosial suami dengan ketidakikutsertaan senam hamil 


\section{PEMBAHASAN}

Senam hamil merupakan suatu gerakan senam guna melatihfisik seseorang. Latihan yang dilakukan selama masa kehamilan dengan kriteria khusus yang perlu diketahui responden yang diharapkan akan mampu menolong ibu dalam menghadapi keluhan yang dialami selama kehamilan khususnya yaitu untuk melatih bagaimana melakukan memanajemenpernafasan menjelang persalinan. Sehingga pada saat proses persalinan berlangsung diharapkan ibu dapat rileks serta menguasai keadaan tubuhnya. ${ }^{6}$ Keikutsertaan ibu dalam kegiatan senam hamil adalah turut serta atau kehadiran ibu hamil di fasilitas kesehatan yang tersedia setempat dengan fasiitas tambahan berupa kegiatan senam hamil. Keikutsertaan ibu hamil dapat mendukung keberhasilan program yang pada dasarnya bagi kepentingan seluruh ibu hamil Indonesia dalam mengatasi permasalahan periode massa kehamilan, bersalin dan nifas bahkan pada new born baby. Berdasarkan hasil penelitian yang telah dilakukan oleh peneliti bertempat di Desa Pandanmulyo Kecamatan Tajinan Kabupaten Malang pada bulan OktoberDesember 2017 menunjukkan bahwa presentase keikutsertaan senam hamil sebesar $57,1 \%$ atau sebanyak 25 responden dari 35 ibu hamil.

Pada hasil diatas dapat dinilai bahwa selain kurangnya pengetahuan pada ibu hamil akan penting dan banyaknya benefitsdari senam hamil juga dikarenakan tidak semua orang gemar, suka atau bahkan merasa perludalam melakukan kegiatan fisik

khususnya yaitu senam hamil. Ibu hamil yang mendapatkan dukungan secara fisik dan psikologis khususnya akan merasa nyaman karena kebutuhan dapat terpenuhi sehingga memotivasi ibu untuk ikutserta dalam kegiatan senam hamil.Dukungan dari pasangan akan dapat meningkatkan kesiapan ibu hamil dalam menghadapi kehamilan mereka hingga proses persalinan. Keterlibatan suami sejak awal kehamilan dapat menyederhanakan dan meringankan beban ibu hamil dalam menjalani dan mengatasi berbagai perubahan dalam tubuh. Hal ini ditujukan untuk kesehatan ibu selama kehamilan, persalinan dan postpartum termasuk kesehatan bayi baru lahir dan bahkan kebutuhan kontrasepsi / keluarga berencana pasca melahirkan untuk mendapat perhatian dan tanggung jawab seluruh keluarga terutama keterlibatan pasangan. ${ }^{7}$

\section{Hubungan Karakteristik Ibu Hamil (Usia, Paritas, Pendidikan) Dengan Keikutsertaan Senam Hamil}

Keikutsertaan pada senam hamil dilihat dari penelitian hasil ini apabila dilihat dari usia ibu menunjukkan bahwa ibu hamil dengan usia reproduksi sehat yaitu kisaran usia 20-35 tahun lebih tinggi keikutsertaan senam hamil di tempat fasilitas kesehatan yang tersedia yaitu sebesar $48,6 \%$ atau 17 responden, dibandingkan dengan usia reproduksi tidak sehat yaitu usia $<20$ tahun atau $>35$ tahun sebanyak $8,6 \%$ atau hanya 3 responden yang mengikuti senam hamil. Didapatkan hasil dari analisis bahwa terdapat hubungan baik antara usia ibu dengan keikutsertaan kegiatan senam hamiil dengan $p$ sebesar 0,006 , diketahui bila $<5 \%$ atau 0,05 menunjukkan bahwa terdapat hubungan antara usia respondendengan keikutsertaan senam hamil. Dalam hal ini sebagian besar dari ibu hamil dengan usia ibu 20-35 tahun memiliki hasil yang tinggi terhadap keikutsertaan senam hamil yang mana ibu mengetahui akan pentingnya kebutuhan dari kesehatannya selama masa kehamilan berlangsung. Usia ibu hamil akan lebih baik jika tidak "terlalu" baik terlalu muda maupunterlalu tua. 
Pada ibu hamil dengan usia $<20$ tahun rentan akan mengalami berbagai komplikasi masalah kehamilan akibat dari belum siapnya organ reproduksi untuk bekerja, sedangkan pada ibu yang berusia >35 tahun khususnya pada kesehatan reproduksi telah mengalami penurunan fungsi. ${ }^{8,11}$

Faktor dari karakteristik lain yang mana dapat mempengaruhi keikutsertaan senam hamil yaitu jumlah kehamilan atau paritas ibu. Hasil dari penielitian ini menunjukkan bahwa pada responden dengan paritas multipara lebih tinggi keikutsertaannya sebesar $31,4 \%$ dibandingkan pada ibu hamil primipara sebesar $25,7 \%$ dalam keikutsertaan senam hamil. Hasil dari analisis bivariat didapatkan hasil bahwa terdapat hubungan paritas responden hamil dengan keikutsertaan kegiatan senam hamil yang ditunjukkan padap sebesar 0,046. Dapat diasumsikan bahwakeikutsertaan kegiatan pada ibu hamil dengan paritas multipara ini bukan merupakan suatu hal yang asing atau baru bagi ibu dan pasangan, berbekal dari pengalaman sebelumnya mereka termotivasi dalam meningkatkan derajat kesehata dalam menghadapi masa kehamilan.

Keikutsertaan responden dalam senam hamil apabila dilihat dari pendidikan yang telah ditempuh ibu hamil pada penelitian ini bahwa ibu dengan kategori pada pendidikan tinggi (SMA-PT) diiketahui lebih tinggi tingkat keikusertaan dalam kegiatan fisik selama hamil yaitu senam hamil sebesar $34,4 \%$ atau 12 resonden, dibandingkan respondenpregnancy dengan tingkat pendidikan yang rendah (SD-SMP) sebesar 22,9\% atau 8 responden yang ikutserta di kegiatan senam hamil. Berdasarkan hasiluji analisis yangdidapatkanp value sebesar 0,018. Hal tersebut dapat diasumsikan bahwa responden penelitian ini yang memiliki pendidikan tinggi akan cenderung memiliki pemikiran yang baik dalammemahami berbagaiinformasi yang didapat terkait kesehatan khususnya selama masa kehamilan, sehingga ibu dengan pendidikan tinggi akan lebih sadar dan menganggap penting untuk mengikuti senam hamil.

\section{Hubungan Dukungan Sosial Suami Dengan Keikutsertaan Senam Hamil}

Dari hasil peneliitian ini juga menunjukkan responden dengan sosial dukungan suami yang tinggi tingkat keikutsertaan senam hamilsebanyak $37,1 \%$ dibandingakan dengan ibu hamil yang mendapat sosial dukungan suami reendah sebesar $20,0 \%$ dan berdasarkan analisis bivariat bahwa adanya hubungan sosial dukungan suami terhadap keikutsertaan senam hamil dengan hasilp value sebesar 0,025 , diketahui bila $<5 \%$ atau 0,05 menunjukkan bahwa terdapat hubungan yang positif dan signifikan antara dukungan sosial suami terhadap keikutsertaan senam hamil.

Hasil penelitian ini sejalan dengan penelitian berupa survey di England $(\mathrm{N}=$ 4616) pada responden yang hamil dengan usia responden lebih dari 16th tahun. Hasil dari analisis univariat dilakukan dengan menggunakan statistik chis square dengan regresi logistik biner menggunakan SPSSX versi 17 \& 19 yang digunakan dalam memperkirakanefek kombinasi dari variabel tersebut terhadap reaksi pasangan terhadap kehamilan mereka, adanya pemeriksaan antenataldan persalinan serta keterlibatan dalam perawatan pasca kelahiran bayi. Lebih dari $80 \%$ suamisenang danmerasa enjoy serta antusiasdalam menanggapi kehamilan pasangan mereka, lebih dari setengahnyapasangan hadir untuk menemani tes kehamilan, sedangkan pasangan menemani satu atau lebih pemeriksaan kehamilan atau antenatal care (ANC), dan hampir semuanya hadir dalam jadwal

pemeriksaaan 
ultrasound.peran Pasangan yang lebih besar dalam keterlibatan pemeriksaan ini memiliki hubungan positif signifikan serta memiliki peran penting dalam mendukung pasangan mereka dalam hal ini istri yang sedang dalam masa kritis dalam kehidupan yaitu masa kehamilan. ${ }^{9}$

Pada jurnal penelitian yang dilakukan pada penelitian partisipatif berbasis kemitraan masyarakatyang berafiliasi dengan Community DetroitAcademic Urban Research Center, telah dilakukanpada tahun 20002001 di sebelah timur dan barat daya Detroit, Thornton, Pamela., Kiefferbahwa sebagian besar perilaku ibu dalam beraktifitas fisik yaitu senam hamil merupakan dampak dari dukungan yang diberikan oleh pasangan mereka. ${ }^{10,13}$ Adanya dukungan suami berupa motivasi aupun informasi berperan besar dalam pengambilan keputusan dan menentukan status kesehatan ibu. Keterlibatan orang terdekat khususnyaketerlibatan suami dapat menjadi batu loncatanterhadap perubahan dalam meningkatkan derajat kesehatan keluarga.Suatu keputusan atau tindakan, dimana salah satu dukungan dari factor reinforcing yang bias mengalihkan seseorang dalam bersikap dan berperilaku. ${ }^{14,15}$ Suami juga dihiarapkan dapat selalu menjadi suami yang siaga dimana selalu memberii perhatian utama terhadap keselamatan dan kesehatan responden hamil. Dukungan pasangan begitu memiliki peran penting dalam menciptakan perilaku bersih dan sehat melewati saran, motivasi maupun gurauan dari suaminya sehingga dukungan sosial suami menjadi faktor yang besar hubungannya atau kaitannya dengan keikutsertaan ibu dalam mengikuti kegiatan senam hamil. ${ }^{16}$

\section{SIMPULAN}

Hasil penelitian menunjukkan bahwa ada hubungan antara karakteristik ibu hamil (usia, paritas, pendidikan) dan dukungan sosial suami dengan keikutsetaan senam hamil di Desa Pandanmulyo.Penelitian ini menunjukkan bahwa keikutsertaan senam hamil pada ibu hamil dengan usia kehamilan $>22$ minggu di Desa Pandanmulyo Kecamatan Tajinan Kabupaten Malang sebesar 57,1\%.Variabel karakteristiik responden terdiri dari paritas,usiadan pendidikan terbukti berhubungan dengan keikutsertaan senam hamil di Desa Pandanmulyo. Dimana sebanyak 48,6\% dengan usia reproduksi sehat dan $8.6 \%$ dengan usia reproduksi tidak sehat. Pada karakteristik paritas yaitu 31,4\% responden multipara dan sebanyak $25,7 \%$ responden primipara. Sedangkan berdasarkan karakteristik dari segi pendidikan yaitu $34,3 \%$ dengan pendidikan tinggi dan sebanyak $22,9 \%$ dalam kategori pendidikan rendah.

Semua item darisosial dukungan suami yang terdiri dari dukungan informasional, emosional, dukungan instrumental dan penghargaan semua komponen tersebut saling berrhubungan dengan keikutsertaan senam hamil. Dimana sebanyak $37,1 \%$ responden dalam kategori dukungan sosial suami tinggi dan $20,0 \%$ responden dalam kategori dukungan sosial suami rendah.Terdapat hubungan antara karakteristik ibu hamil (usia, paritas dan pedidikan) dengan keikutsertaan senam hamil di Desa Pandanmulyo dengan masing-masing $p$ value usia $=0,006$, paritas $=0,046$ dan pendidikan $=0,018$ serta terdapat pula hubungan antara dukungan sosial suami dengan keikutsertaan senam hamil di Desa Pandanmulyo Kecamatan Tajinan Kabupaten Malang dengan hasil $p$ value 0,025 . 


\section{DAFTAR PUSTAKA}

1. Manuaba, I. C. 2008. GawatDarurat Obstetri-Ginekologi dan Obstetri-Ginekologi Sosial untuk Profesi Bidan. Jakarta: EGC.

2. Kemenkes RI. 2011. Pedoman Pelaksanaan Kelas lbu Hamil Tahun 2011. Buku Pedoman Pelalaksanaan Kelas Ibu hamil (pp. 1-26). Jakarta.

3. Wiknjosastro, H. 2012. IImu Kebidanan. Jakarta: Bina Pustaka.

4. Sarafino, E. P., \& Smith, T. W. 2014. Health psychology biopsychological interaction (8th ed.). New York: Wiley.

5. Puskesmas Tajinan. 2017. Laporan Ibu Hamil 2017 Kecamatan Tajinan Kabupaten Malang. Tajinan

6. Depkes RI. 2009. Pegangan Fasilitator Kelas Ibu Hamil Tahun 2009. Pegangan Fasilitator Kelas Ibu Hamil (p. 72). Jakarta: Departemen Kesehatan RI.

7. Kemenkes RI. 2013. Situasi Keluarga Berencana di Indonesia. In Buletin Jendela Data dan Informasi.

8. Depkes RI. 2006. Ibu Sehat Bayi Sehat. Jakarta: Departemen Kesehatan RI.

9. Redshaw, M., \& Henderson, J. 2013. Fathers ' engagement in pregnancy and childbirth : evidence from a national survey. BMC Pregnancy and Childbirth, 13(70), $1-15$.

10. Thornton PL, Kieffer EC, Salabarría-Peña $\mathrm{Y}$, Odoms-Young A, Willis $\mathrm{SK}, \mathrm{Kim} \mathrm{H}$, et al. Weight, diet, and physical activity-related beliefs and practices among pregnant and postpartum Latino women: The role of social support. Matern Child Health J. 2006;10:95-104. [PubMed]

11. Depkes RI. 2008. Panduan Pelaksanaan Strategi Making Pregnancy Safer (MPS) and Child Survival. Jakarta: Departemen Kesehatan RI.
12. Bandura. A. 2001. Social Cognitive Theory: An Agentic Perspective. Annu Rev Psychol 52; 1-26.

13. Cioffi, J., Schmied, V., Dahlen, H., Mills, A., Thornton, C., Duff, M.,. Kolt, G.S. (2010). Physical activity in pregnancy: Women's perceptions, practices, and influencing factors. Journal of Midwifery \& Women's Health, 55, 455-461.

14. Cohen, S., Gottlieb, B. H., \& Underwood, L. G. 2000. Social Reliationships and Health. In Social support measurement and interventions: A guide for health and social scientists. New York: Oxford(pp. 3-25).

15. Mullany, B. C., Becker, S., \& Hindin, M. J. 2007. The impact of including husbands in antenatal health education services on maternal health practices in urban Nepal : results from a randomized controlled trial. Oxford University, 22(2), 166-176.

16. Spoozak, L., Gotman, N., Smith, M. V., Belanger, K., \& A, Kimberly. 2010. Evaluation of a social support measure that may indicate risk of depression during pregnancy. $\mathrm{J}$ Affect Disord of National Institute Health Public Access, USA, 114(13), 216-223. 